\title{
The $B$ in 'BDM.' William Bateson did not advocate a genic speciation theory
}

Heredity (2011) 106, 202; doi:10.1038/hdy.2010.15; published online 17 February 2010

In his commentary 'One hundred years after Bateson,' Johnson (2009) refers to demonstrations of incompatibilities between the products of putative speciation genes that provide 'further proof of principle of the model proposed by Bateson (1909) and extended by Dobzhansky (1937), Muller (1942) and subsequent geneticists.' Such 'Bateson-Dobzhansky-Muller (BDM) incompatibilities' are held to 'form the basic paradigm for much of the current theory on the evolution of reproductive isolation, and therefore the formation of species.'

However, while citing Lewis (2009), Johnson does not mention that Lewis urges caution 'in labeling gene incompatibilities as speciation genes,' and 'in interpreting them as being causal in the speciation process rather than a result of divergence post-speciation.' Furthermore, while citing the yeast studies of Greig (2009), Johnson does not mention Greig's suggestion that speciation is simply due to 'sequence divergence,' which generates meiotic 'antirecombination,' namely 'the inability of diverged chromosomes to form crossovers' because of non-genic chromosomal incompatibilities. Likewise, from introgression studies in fruit fly, it was suggested that chromosomal incompatibilities were due to 'foreign DNA amount' and not due to its coding potential (Naviera and Maside, 1998). A classic speciation gene causing tumors in interspecies fish hybrids has been brought into question (Schartl, 2008).

As these studies support the non-genic view that William Bateson expounded in the early decades of the twentieth century (Forsdyke, 1999, 2001, 2006), your readers may find it strange that Bateson's name is linked to the genic viewpoint of Dobzhansky and Muller. It is true that theirs is a model of interaction between genes, and that Bateson introduced the term 'epistasis' to describe such interactions. But a careful contextual reading of Bateson shows that he attributed speciation to a non-genic 'residue' that can now be equated with divergence in DNA base compositions (Cock and Forsdyke, 2008; Forsdyke, 2009, 2010).

\section{Conflict of interest}

The author declares no conflict of interest.

\author{
DR Forsdyke \\ Department of Biochemistry, Queen's University, Kingston, \\ Ontario, Canada \\ E-mail: forsdyke@queensu.ca
}

\section{References}

Bateson W (1909). Heredity and variation in modern lights. In: Seward AC (ed). Darwin and Modern Science. Cambridge University Press: Cambridge, pp 85-101.

Cock AG, Forsdyke DR (2008). "Treasure Your Exceptions." The Science and Life of William Bateson. Springer: New York.

Dobzhansky T (1937). Genetics and the Origin of Species. Columbia University Press: New York.

Forsdyke DR (1999). Two levels of information in DNA. Relationship of Romanes' 'intrinsic' peculiarity of the reproductive system, and Bateson's 'residue,' to the species-dependent component of the base composition, $(\mathrm{C}+\mathrm{G}) \%$. J Theor Biol 201: 47-61.

Forsdyke DR (2001). The Origin of Species, Revisited. A Victorian who Anticipated Modern Developments in Darwin's Theory. McGill-Queen's University Press: Montreal.

Forsdyke DR (2006). Evolutionary Bioinformatics. Springer: New York.

Forsdyke DR (2009). Bateson's contributions to evolutionary theory. Address to the John Innes Centre Centenary Symposium-History of Genetics Day http://avsleccap. uea.ac.uk/mediasite/Viewer/?peid = 8636067d92f54002acelea 9f998ff06a.

Forsdyke DR (2010). George Romanes, William Bateson, and Darwin's 'weak point'. Notes Rec $R$ Soc 64 (in press; doi:10.1098/rsnr.2009.0045).

Greig D (2009). Reproductive isolation in Saccharomyces. Heredity 102: 39-44.

Johnson NA (2009). One hundred years after Bateson: a pair of incompatible genes underlying hybrid sterility between yeast species. Heredity 103: 360-361.

Lewis EJ (2009). Origins of reproductive isolation. Nature 457: 549-550.

Muller HJ (1942). Isolating mechanisms, evolution and temperature. Biol Symp 6: 71-125.

Naviera HF, Maside XR (1998). The genetics of hybrid male sterility in Drosophila. In: Howard DJ, Berlocher SH (eds). Endless Forms. Species and Speciation. Oxford University Press: Oxford, pp 330-338.

Schartl M (2008). Evolution of Xmrk: an oncogene, but also a speciation gene? BioEssays 30: 822-832. 